Available online at website :

http://e-journal.adpgmiindonesia.com/index.php/jmie

JMIE: Journal of Madrasah Ibtidaiyah Education, 4(1), 2020, 68-85

\title{
STRATEGI PERPUSTAKAAN SEKOLAH DASAR DALAM MENGEMBANGKAN EMOTIONAL BRANDING MELALUI STORYTELLING
}

\author{
Rahmat Fadhli'), Rosiana Nurwa Indah'2), Novi Widya'), Wulan Oktaviani ${ }^{4)}$ \\ Universitas Negeri Yogyakarta1), Universitas Islam Nusantara2),3,4) \\ Email: rahmat.fadhli@uny.ac.id ${ }^{1)}$,rosianaindah7@gmail.com²),novi.widya@uninus.ac.id³), \\ wulanoktaviani025@gmail.com ${ }^{4}$
}

Naskah diterima : 15 Maret 2020, direvisi : 25 April 2020, disetujui : 30 April 2020

\begin{abstract}
This study aims to discuss how the implementation of storytelling activities in the library and discuss how school library develops emotional branding through storytelling in SDN 035 Soka Bandung. The research method used is qualitative. The informants in this study consisted of the Head of the Library, Librarian, Teachers and Students. Data collection methods namely observation, in-depth interviews and literature studies. Data analysis techniques, namely data reduction by open coding, data presentation and conclusions. The results of this study are the implementation of storytelling activities in the library to support the school literacy movement program and to have a positive impact on students such as increasing interest in visiting the library, increasing interest in reading and writing and improving students' communication skills. The storytelling program in terms of emotional branding becomes elementary school library strategy in creating a positive image of the library user so that the library user becomes loyal using the library and creates an emotional intimacy between the librarian and the user. Librarians act as key actors in developing storytelling as an emotional branding strategy by conducting competency development activities in storytelling, collection development and the quality and quantity of school library services.
\end{abstract}

Keywords: emotional branding, school library, storytelling

Pengutipan: Fadhli, Rahmat, dkk. (2020). Strategi Perpustakaan Sekolah Dasar dalam Mengembangkan Emotional Branding Melalui Storytelling. JMIE: Journal of Madrasab Ibtidaiyah Education,4(1), 68-85. jmie.v4i1.172. 


\section{PENDAHULUAN}

Keberadaan perpustakaan saat ini sebagai penyedia informasi dengan berbagai literatur baik tercetak maupun non cetak, dimana semua informasi yang dikelola dapat digunakan untuk memenuhi kebutuhan informasi pemustaka. Menanggapi beragamnya jenis koleksi, banyaknya sumber informasi serta beragamnya pemustaka, perpustakaan pada perkembangannya juga memiliki beberapa jenis yang menyesuaikan tujuan dan fungsinya masing-masing. Jenis tersebut seperti perpustakaan Nasional, perpustakaan umum, perpustakaan perguruan tinggi, perpustakaan sekolah dan perpustakaan khusus.

Penyelenggaraan perpustakaan, khususnya pada lingkungan pendidikan berkaitan erat dengan Undang-Undang No.20 Tahun 2003 tentang Sistem Pendidikan Nasional. Pada Undang-Undang tersebut dijelaskan dalam upaya menyelenggarakan pendidikan yang baik, satuan pendidikan perlu didukung oleh sumber daya pendidikan yang memadai. Yang dimaksud dengan sumber daya pendidikan adalah segala sesuatu yang dipergunakan dalam penyelenggaraan pendidikan yang meliputi tenaga kependidikan, masyarakat, dana, sarana dan prasarana. Perpustakaan sekolah (school library) menjadi bagian dari sarana dan prasarana ini yang memungkinkan tenaga pendidik, kependidikan, dan peserta didik memperoleh kesempatan untuk memperluas dan memperdalam pengetahuan (Sumiati, 2018).

Perpustakaan sekolah diartikan sebagai perpustakaan yang berada pada lingkungan sekolah baik negeri ataupun swasta, pendidikan dasar dan menengah yang memberikan informasi kepada siswa dan kebutuhan berkaitan dengan kurikulum kepada guru dan tenaga kependidikan serta mengelola koleksi berupa buku, terbitan berkala dan media pembelajaran untuk mendukung proses pembelajaran dan tujuan sekolah (Bafadal, 2011; Reitz, 2004). Penyelenggaraan perpustakaan sekolah adalah suatu keharusan bagi lembaga pendidikan. Hal ini juga sudah ditekankan pemerintah melalui Undang-Undang No.43 Tahun 2007 tentang Perpustakaan yang disebutkan bahwa setiap sekolah/madrasah menyelenggarakan perpustakaan yang memenuhi standar nasional perpustakaan dengan memperhatikan standar nasional pendidikan. Lebih lanjut disebutkan setiap perpustakaan sekolah wajib memiliki koleksi buku teks wajib serta mengembangkan koleksi lain yang mendukung kurikulum pendidikan.

Pada hakikatnya, keberadaan perpustakaan sekolah memiliki fungsi sebagai sumber belajar, penelitian sederhana, pusat kegiatan literasi informasi, tempat kegiatan baca-membaca, serta tempat penumbuhan kreativitas, inspirasi maupun imajinasi bagi para siswa (Lasa, 2013). Fungsi tersebut pada dasarnya merupakan turunan umum dari fungsi perpustakaan yang terdiri atas fungsi pendidikan, informasi, penelitian, penyimpanan dan rekreasi. Selanjutnya fungsifungsi tersebut diimplementasikan melalui koleksi ataupun layanan yang disediakan oleh pustakawan atau guru-pustakawan. Selain itu, keberadaan perpustakaan sekolah juga memiliki peran strategis dalam menumbuhkan minat baca pada siswa. Untuk menjalankan hal tersebut 
dibutuhkan peran aktif pustakawan melalui kegiatan promosi membaca yang dapat mempengaruhi kemampuan kognitif, afektif dan psikomotorik siswa (Merga, 2019; Oriogu, 2015). Oleh karena itu, pustakawan harus mampu membantu dan menyediakan informasi serta layanan untuk perkembangan kemampuan dan keterampilan berpikir siswa.

Layanan perpustakaan saat ini berkembang pesat khususnya di perpustakaan sekolah. Perpustakaan tidak hanya menyediakan koleksi dan layanan peminjaman saja, namun sudah berupaya memaksimalkan fungsi-fungsi perpustakaan secara umum. Layanan mendongeng atau populer dengan istilah storytelling merupakan salah satu layanan yang eksis pada perpustakaan sekolah, khususnya sekolah dasar. Storytelling dapat diartikan sebagai menceritakan cerita atau suatu cara atau teknik yang dilakukan untuk menyampaikan suatu cerita pada penyimak dalam bentuk kata-kata, gambar, foto ataupun suara. Metode ini menjadi salah satu metode yang efektif untuk mengenalkan membaca pada anak-anak sejak dini (Asri, Wulandari, \& Jariyah, 2019). Storytelling atau mendongeng adalah suatu aktivitas bercerita dalam menyampaikan cerita, baik fiksi maupun non fiksi diamana yang disesuaikan pendengar (komunikator) yang akan dituju, dan isi cerita disesuaikan dengan usia yang akan kita ajak bercerita. Storytelling mempunyai peran positif dalam mendidik anak salah satunya anak dapat meniru teladan dalam tokoh yang di ceritakan tanpa menasehati anak akan memahami perilaku yang baik yang pantas dilakukan di lingkungan kesehariannya. Menurut Agosto (2016) terdapat tiga dampak utama pada kegiatan storytelling. Pertama, membuat pendengar dapat masuk lebih dalam ke cerita sehingga lebih menghayati. Kedua, membangun komunitas antara siswa dan pencerita/guru, menningkatkan daya ingat, mendukungan pengembangan literasi awal dan menciptakan pola pikir yang kreatif (creative thinking). Ketiga, peningkatan literasi pada anak.

Pada penelitian yang sudah dilakukan, banyak penelitian berkaitan dengan storytelling di perpustakaan yang dianalisis dengan berbagai aspek. Berdasarkan penelitian terdahulu, pelaksanaan storytelling di perpustakaan memiliki banyak dampak positif. Implementasi storytelling pada perpustakaan TK/SD dapat digunakan sebagai salah satu sarana pembelajaran bagi siswa dan sarana promosi bagi perpustakaan melalui koleksi buku sebagai media cerita (Sophiani, 2008). Kegiatan storytelling juga memiliki pengaruh positif terhadap minat kunjung anak-anak ke perpustakaan (Yolanda \& Hermintoyo, 2014; Yulfiandri \& Nelisa, 2015). Selain itu, kegiatan storytelling di perpustakaan juga memberikan dampak dalam mengembangkan imajinasi anak, memperkenalkan cerita pada anak (Indriani, Johan, \& Agustina, 2017) dan kegiatan ini dapat meningkatkan peminjaman pada layanan sirkulasi di perpustakaan (Indriani et al., 2017; Sturm, Riddle, \& Fox, 2017).

Salah satu dampak program perpustakaan seperti storytelling pada pemustaka adalah terciptanya hubungan positif antara pemustaka dan pustakawan. Pada dasarnya strategi tersebut dapat dikatakan sebagai strategi emotional branding yang menjadi paradigma baru untuk mendekatkan dan menghubungkan antara konsumen dengan brand secara dalam aspek 
emotional atau kedekatan (Devi \& Sharma, 2015; Komariah, Rodiah, \& Saepudin, 2016), dalam konteks ini antara pihak perpustakaan dan pustakawan. Pada perpustakaan sekolah tentunya perlu diterapkan konsep emotional branding sehingga dapat menciptakan kedekatan secara emosional antara kedua pihak, sehingga pemustaka bersifat loyal ke perpustakaan.

Perpustakaan Sekolah Dasar Negeri 035 Soka Bandung merupakan salah satu perpustakaan sekolah yang sudah memaksimalkan beberapa layanan berkaitan dengan literasi khususnya storytelling. Layanan ini dioptimalkan oleh pustakawan sekolah secara rutin dengan memanfaatkan koleksi perpustakaan untuk meningkatkan daya guna koleksi perpustakaan kepada para siswa. Kegiatan layanan ini diikuti oleh seluruh siswa sekolah dengan porsi yang berbeda-beda setiap tingkatan kelasnya. Berdasarkan kondisi tersebut, melalui kegiatan tersebut dapat dibangun kedekatan emosional antara pustakawan dengan siswa di lingkungan SDN 035 Soka Bandung. Dengan demikian, penelitian ini tertarik membahas bagaimana implementasi kegiatan storytelling serta membahas bagaimana kegiatan storytelling dilihat dari aspek emotional branding.

\section{METODE PENELITIAN}

Penelitian ini menggunakan metode penelitian kualitatif. Pengertian metode penelitian kualitatif, yaitu penelitian yang bermaksud untuk memahami fenomena tentang apa yang dialami oleh subjek penelitian, misalnya perilaku, persepsi, motivasi, tindakan dan lain-lain secara holistik dan dengan cara deskriptif dalam bentuk kata-kata dan bahasa, pada suatu konteks khusus yang alamiah dan dengan memanfaatkan berbagai metode alamiah (Moleong, 2011). Penelitian di fokuskan pada Informan dalam penelitian ini adalah kepala perpustakaan dan pustakawan Perpustakaan, Guru serta siswa di SD Negeri 035 Soka Bandung.

Teknik pengumpulan data dalam penelitian melalui observasi, wawancara, dan studi dokumen. Observasi dilakukan untuk mengamati berbagai peristiwa, kegiatan dan sejenisnya sehingga diperoleh keterangan yang berkaitan dengan topik penelitian. Wawancara dilakukan untuk mengumpulkan data utama yang akan digunakan dalam penelitian, yaitu dengan melakukan wawancara tidak terstruktur kepada kepala perpustakaan dan pustakawan sebagai informan. Studi dokumen dilakukan melalui berbagai literatur dan penelitian terdahulu yang berkaitan dengan topik penelitian ini. Adapun teknik analisa data menggunakan model analisis Miles, Huberman, \& Saldana (2014) yaitu kondensasi data, penyajian data, dan penarikan kesimpulan. 


\section{Tabel 1. Contoh Open Coding}

Koding transkrip wawancara diolah bulan Maret 2019 dengan informan CC dengan mengajukan pertanyaan. Transkrip ini dengan pertanyaan utama "Bagaimana latar belakang pelaksanaan program storytelling yang dikembangkan oleh perpustakaan?"

Transkrip Wawancara

P: Bagaimana pentingnya dan dampak dari program storytelling yang dilakukan oleh perpustakaan saat ini?

I: Pendapat saya setelah di adakan program Literasi yang di bawahnya ada layanan storytelling untuk pemustaka yang di sampaikan oleh pustakawan itu sangat berpengaruh baik untuk peningkatan literasi anak dan secara tidak langsung mengajarkan kepada anak salah satu contoh nya yaitu berani dan melatih berbicara di depan teman temannya, kemudian saya liat juga setelah diadakan layanan storytelling anak menjadi sering ke perpustakaan dan pemanfaatakn koleksi perpustakaan meningkat, efek ke anak nya juga sangat terlihat dan anak pun antusias saat kegiatan tersebut berlangsung, dan kegiatan ini sangat saya apresiasi dan sangat produktif dalam meningkatkan minat anak"

\section{P: Kapan program storytelling dilakukan oleh perpustakaan?}

I: Kita mengeadakan kegiatan ini 2 minggu sekali tiap hari selasa di bagi antara 2 minggu kelas bawah yaitu kelas 1 (satu) sampai kelas 3 (tiga) dan 2 minggu selanjutnya kelas atas yaitu kelas 4 (empat) sampai kelas 6 (enam) dan itu rutin. Serta suka ada perpustakaan keliling dari DISPUSIPDA (Dinas Perpustakaan \& Arsip Daerah JawaBarat) setiap seminggu sekali tepatnya hari selasa nah disana juga kadang kita mengadakan storytelling hanya saja misal kalau pas jam istirahat kelas 3 (tiga) kita ber storytelling hanya untuk 1 kelas itu dan kadang itupun tidak semua anak karena disini ada 6 rombel yaitu kelas A-f, terkadang juga apabila pas istirahat ada anak ke perpustakaan ingin mendengarkan storytelling maka kita adakan baik itu hanya 5orang. Tapi rutin dan yang sudah terjadwal yaitu 2minggu sekali setiap hari selasa yang di bagi antara kelas bawah dan atas. Dan keinginan kita agar terciptanya anak mau berkunjung ke perpustakaan

\section{Open Coding}

Pendukung program

literasi sekolah

-mengajarkan

kemampuan

komunikasi siswa

Siswa antusias

menggunakan dan

berkunjung ke

perpustakaan

- Program dilakukan

berkelanjutan

- Siswa dibagi menjadi dua kelompok besar.

- Terdapat program tambahan sesuai dengan kondisi 
Validitas data pada penelitian ini menggunakan teknik triangulasi, dimana data yang sudah didapatkan oleh peneliti melalui wawacara, dan observasi dilakukan validasi menggunakan studi literature/dokumen.

\section{HASIL DAN PEMBAHASAN}

\section{Implementasi Program Storytelling}

Pelaksanaan program storytelling di Perpustakaan SDN 035 Soka Bandung didasari dan dilatabelakangi oleh pengembangan literasi di lingkungan sekolah, khususnya SDN 035 Soka Bandung. Program ini juga dikembangkan atas dasar kesadaran pustakawan dalam menumbuhkan kemampuan literasi pada anak sejak dini. Hal ini sesuai dengan kutipan wawancara di bawah ini:

"Program storytelling ini berada dibawah payung program literasi yang diselenggarakan oleh perpustakaan sekolah. Khusus layanan ini juga diberikan dan disampaikan oleh pustakawan dan dilihat memiliki pengaruh yang baik untuk peningkatan literasi anak..." (I1/CC/KP/04-2017/4)

Selain itu, pelaksanaan program storytelling berjalan tidak hanya digerakkan oleh bagian perpustakaan sekolah saja, namun juga mendapatkan dukungan dari pihak guru seperti kutipan wawancara berikut:

"Pendapat saya tentang diadakan nya ini sangat baik dan sangat bagus bagi pertumbuhan daya ingat dan daya pikir anak bahkan dengan adanya storytelling ini yang diadakan oleh pustakawan meningkatkan dan melatih daya kreatif anak dalam berfikir, menjadikan anak lebih bersemangat dalam mendengarkan..." (I3/YM/GR/04$2017 / 1)$

Berdasarkan hasil penelitian ini, kegiatan storytelling yang diselenggarakan oleh perpustakaan SDN 035 Soka Bandung digolongkan pada implementasi Gerakan Literasi Sekolah (GLS) yang dikenalkan oleh Kementerian Pendidikan dan Kebudayaan pada sejak tahun 2015. Gerakan ini bertujuan untuk menumbuhkembangkan budi pekerti siswa dengan pembudayaan ekosistem literasi sekolah agar siswa dapat menjadi pembelajar sepanjang hayat (Kementerian Pendidikan dan Kebudayaan RI, 2016). Gerakan Literasi Sekolah (GLS) pada lingkungan SD terdapat tiga tahap pelaksanaan yang terdiri atas tahap pembiasaan, pengembangan dan pembelajaran. Analisis pada penelitian ini menyimpulan pelaksanaan kegiatan ini digolongkan pada tahapan pembiasaan atau tahapan awal pada pengembangan literasi sekolah. Tahapan ini menekankan pada penumbuhan minat siswa terhadap kegiatan membaca dan bahan bacaan. Pada tahap ini juga terdapat unsur pelibatan publik dimana storytelling atau memberikan cerita merupakan salah satu langkah yang dapat dilakukan berbagai 
pihak termasuk didalamnya sekolah dalam membiasakan dan mendidik anak agar memiliki minat dalam membaca (Antasari, 2017).

Pada implementasi ini, perpustakaan memiliki peran penting dalam meningkatkan budaya literasi pada warga sekolah khususnya pada kalangan siswa. Hal ini sejalan dengan salah satu unsur pada tahap pembiasaan yakni penataaan sarana dan lingkungan kaya literasi yang salah satunya adalah perpustakaan. Pada panduan Gerakan Literasi Sekolah di Sekolah Dasar, perpustakaan meliki fungsi sebagai pusat pengelolaan pengetahuan dan sumber belajar di sekolah dasar. Oleh karena itu, penting bagi perpustakaan menciptakan lingkungan yang kaya akan teks seperti karya peserta didik berupa tulisan, gambar atau grafik, poster pelajaran, kampanye membaca, kliping, buku dan sumber informasi lainnya termasuk informasi elektronik, kaset cerita, atau bahan digital lainnya. Berdasarkan observasi dan studi dokumen dari perpustakaan SDN 035 Soka Bandung, Perpustakaan sudah cukup lengkap menyediakan literatur dengan jumlah 7.912 eksemplar yang terdiri atas 4.345 judul. Koleksi yang disediakan tersebut mencakup seluruh bidang ilmu baik pada golongan koleksi sirkulasi ataupun koleksi referensi.

Berdasarkan hasil observasi, pelaksanaan program storytelling di perpustakaan SDN 035 Soka Bandung dibagi menjadi dua kelas besar yakni kelas rendah yang terdiri atas siswa kelas 1 sampai kelas 3, dan kelas tinggi yang terdiri atas siswa kelas 4 sampai kelas 6. Kegiatan berlangsung secara terus menerus dalam dua minggu sekali untuk masing-masing kelompok. Sedangkan tema cerita atau media buku yang digunakan dalam storytelling sudah disesuaikan oleh pustakawan dengan karakteristik siswa berdasarkan umur. Koleksi yang digunakan pada kelas rendah adalah koleksi berupa fabel, atau cerita khayalan belaka yang berisi tentang kehidupan hewan yang berperilaku atau memiliki sifat seperti manusia. Sedangkan bagi kelas tinggi dipilih buku yang kontennya lebih berat dibandingkan buku fabel, seperti buku dongeng, koleksi fiksi ataupun cerita singkat. Beberapa bentuk koleksi rekreatif tersebut memang cukup populer digunakan sebagai sumber bacaan pada storytelling karena konten atau cerita mudah dipahami siswa serta melatih daya imajinasi siswa. Pada beberapa buku juga ditemukan gambar pendukung yang memudahkan siswa untuk memahami situasi ataupun gambaran peristiwa yang diceritakan. Hal ini sesuai dengan jenis-jenis storytelling yang dijelaskan oleh Rosidatun (2018) yakni fabel atau dongeng tentang dunia binatang; legenda, dongen tentang kejadian suatu tempat; Mite, dongen tentang dewa-dewa; Sage, dongeng yang berkaitan dengan unsur sejarah serta parable, dongeng yang mengandung nilai pendidikan atau cerita pendek sederhana.

Disamping itu, disebutkan bahwa dengan pelaksanaan program storytelling yang dilakukan di sekolah memiliki dampak positif bagi siswa diantaranya menumbuhkan daya ingat dan daya berpikir siswa, meningkatkan siswa dalam berpikir kreatif dan melatih siswa dalam mendengarkan dan berkomunikasi. Hal ini dapat disimpulkan storytelling dapat memberikan 
banyak dampak positif terhadap perkembangan siswa dalam proses pembelajaran ataupun yang berhubungan dengan peningkatan literasi. Menurut Agosto (2016), pemberian storytelling pada siswa memberikan empat dampak utama yang berkaitan dengan literasi. Pertama, visualisasi (visualization) yakni meningkatkan kemampuan siswa dalam menangkap gambaran cerita ataupun informasi lainnya yang tertulis ataupun yang didengarkan. Secara langsung ini adalah salah satu fondasi dari kemampuan literasi yang harus dimiliki oleh anak atau siswa. Kedua, peningkatan kognitif atau cognitive engagement. Hal ini didapatkan jika pembaca atau pendengar tertarik dengan cerita ataupun bahan bacaan, secara langsung mereka akan termotivasi untuk memahami cerita tersebut. Hal ini akan mengasah kemampuan kognitif siswa. Ketiga, berpikir kritis (critical thinking). Dampak ini berkaitan erat dengan peningkatan kognitif. Anak atau siswa akan menerapkan pola berpikir kritis saat mendengar ataupun membaca cerita. Keempat, kemampuan mengurutkan cerita (story sequencing ability). Kemampuan ini adalah kecakapan untuk mengidentifikasi kejadian atau peristiwa yang berbeda dalam sebuah cerita secara kronologis.

Sedangkan menurut siswa, layanan storytelling yang diberikan oleh perpustakaan mendapat sambutan positif. Berdasarkan analisis data kualitatif hasil wawancara singkat kepada siswa dengan tahapan koding yang dilakukan, peneliti melakukan interprestasi dan kategorisasi data, terdapat tiga kategorisasi terhadap respon siswa terhadap layanan storytelling di perpustakaan sekolah. Pertama, meningkatkan minat kunjung siswa ke perpustakaan. Dengan adanya kegiatan storytelling, siswa menjadi sangat senang dan menjadi suka menghabiskan waktu istirahat dengan berkunjung ke perpustakaan, terutama untuk meminta pustakawan menjadi story teller. Minat kunjung perpustakaan dapat diartikan sebagai kencendrungan atau keinginan terhadap seseorang terhadap perpustakaan. Terdapat beberapa indikator dalam minat kunjung perpustakaan, yakni tahu arti dan mafaat perpustakaan, membutuhkan sesuatu di perpustakaan, tertarik dengan perpustakaan, merasa senang dengan perpustakaan dan dilayani dengan baik (Sutarno, 2006). Hal ini sejalan dengan hasil penelitian yang mengkaji pengaruh pemberian kegiatan storytelling terhadap minat kunjung anak ke perpustakaan di Kota Semarang yang menunjukkan hasil positif. Respon anak-anak terhadap kegiatan bercerita atau storytelling menjadi positif sehingga senang dan sering berkunjung ke perpustakaan (Yolanda \& Hermintoyo, 2014).

Kategori kedua, meningkatkan minat baca dan menulis siswa. Keberadaan program storytelling ini secara tidak langsung meningkatkan gairah siswa dalam membaca. Jenis koleksi yang disukai dalam minat baca ini adalah koleksi yang bersifat rekreatif seperti buku cerita, serta komik. Selain itu, dampak dari program storytelling ini juga membuat siswa menyukai kegiatan menulis. Beberapa diantaranya, melakukan kegiatan menulis cerita dianjutkan menceritakan hasil tulisannya kepada siswa lain termasuk pustakawan atau mendemonstrasikan storytelling. Storytelling memiliki peranan penting dalam meningkatkan kemampuan menulis siswa. Keberadaan storytelling ini mengembangkan imajinasi siswa sehingga dapat dengan 
mudah memperoleh ide dan gagasan saat menulis. Berdasarkan hasil penelitian Wardiah (2017) storytelling membantu siswa yang kurang percaya diri dan keterbatasan dalam mengekspresikan ide-ide yang mereka miliki dengan menulis. Pada penelitian tersebut dijabarkan proses pembelajaran menulis individu dimulai dari membaca, bercerita dan menulis. Sehingga, pada tahapan akhir individu memiliki banyak sumber ide dan gagasan untuk dituangkan. Sehingga pada poin ini sesuai dengan hasil penelitian tersebut yang menyebutkan bahwa kegiatan storytelling berperan dalam meningatkan minat siswa dalam membaca dan meningkatkan kemampuan menulis.

Kategori ketiga yakni meningkatkan kemampuan komunikasi siswa (communication skills). Pada kegiatan storytelling yang dilakukan di Perpustakaan SDN 035 Soka Bandung, pencerita atau story teller tidak hanya diperankan oleh kepala perpustakaan atau pustakawan saja, namun juga melibatkan siswa dalam menceritakan ulang kembali cerita yang mereka baca. Dari hasil penelitian ini, disimpulkan bahwa siswa juga merespon positif kegiatan storytelling sebagai pencerita atau story teller kepada teman-temannya. Hasil penelitian ini juga sejalan dengan penelitian yang sudah dilakukan sebelumnya. Penelitian yang dilakukan Pratiwi (2016) tentang penerapan metode storytelling untuk meningkatkan keterampilan berbicara siswa kelas II sekolah dasar disimpulkan program storytelling dapat meningkatkan keterampilan berbicara siswa. Penelitian ini integrasikan dalam proses pembelajaran bahasa Indonesia dan melihat hasil akhir yakni aspek keterampilan berbicara siswa yang mengalami peningkatan.

Kegiatan storytelling ini dapat menjadi media komunikasi yang efektif dalam menyampaikan suatu informasi ataupun cerita. Hal ini disebabkan pada kegiatan ini akan membentuk individu sebagai pencerita atau story teller melewati berbagai rangkaian aktivitas sebelum melakukan storytelling. Aktivitas tersebut menentukan cerita, menuliskan atau menyiapkan konsep, menyampaikannya dan secara tidak langsung juga secara aktif mengasah keterampilan berbahasa. Hal ini juga didukung dengan penelitian berkaitan dengan keefektifan storytelling dalam mengasah kemampuan komunikasi. Terdapat tiga aspek kunci dalam yang berimplikasi pada kemampuan storytelling sebagai kemampuan komunikasi. Pertama, konten atau isi. Pada tahap ini, individu akan belajar berkaitan dengan membuat storyline atau jalan cerita, menentukan peristiwa pada cerita, menentukan hal yang perlu dan tidak perlu pada cerita, serta koherensi atau kontinuitas cerita. Kedua, aspek bahasa. Memfokuskan pada tata bahasa, pemilihan kata, pelafalan kata, serta kemampuan parafrase cerita dari buku. Ketiga, aspek penyampaian atau delivery. Berkaitan dengan kesiapan, kecakapan berbicara, ketepatan menyampaikan kata, kontak mata (eye contact), penggunaan suara dan intonasi, mimik wajah, gerak tubuh dan komunikasi non verbal serta penggunaan peralatan pendukung (Mokhtar, Halim, \& Kamarulzaman, 2011). 


\section{Emotional Branding melalui kegiatan Storytelling}

Kedekatan emosional adalah rasa kedekatan pada orang lain dan salah satu pengukur intimacy (Yuliawati, 2008). Intimacy menurut adalah sebuah perasaan kedekatan dan keterhubungan dalam suatu hubungan. Adanya intimacy ini nantinya dapat menimbulkan interaksi yang dekat, dan komitmen untuk mendukung sesuatu (Turri, Smith, \& Kemp, 2013).

Terciptanya sebuah kedekatan emosional ini tidak akan terlepas dari adanya emotional branding. Hal ini karena emotional branding dapat membentuk keterikatan konsumen secara mendalam, dalam jangka panjang dan memiliki hubungan emosional dengan sebuah merek (Morrison dan Crane dalam Devi dan Sharma, 2015). Selain itu, melalui emotional branding ini organisasi dapat membangun sebuah respon emosional dan hubungan yang menguntungkan dengan konsumen mereka (Devi \& Sharma, 2015). Emotional branding juga mampu menumbuhkan adanya komitmen, kepuasan, dan loyalitas (Akgün, Koçoğlu, \& İmamoğlu, 2013). Pada konsep emotional branding yang dikenalkan Gobe (2005) terdapat empat pilar dalam pelaksanaannya yakni:

1. Hubungan

Dalam emotional branding terdapat hubungan yang mendalam dan menunjukkan rasa hormat kepada konsumen, sehingga dapat memberikan pengalaman emosional yang benar-benar mereka inginkan. Dengan demikian perusahaan harus benar-benar mengenal siapa konsumennya.

2. Pengalaman panca indra

Adanya suatu pengalaman merek yang berhubungan dengan pancaindra dapat menjadi branding merek yang sangat efektif sehingga dapat menimbulkan kenangan manis, tercipta preferensi merek dan muncul loyalitas.

3. Imajinasi

Imajinasi pada proses emotional branding berupa pendekatan imajinatif dalam produk, kemasan, took ritel, iklan, dan situs web yang melampaui harapan konsumen dan meraih hati konsumen.

4. Visi

Visi dalam emotional branding berkaitan dengan visi yang kuat harus dimiliki sebuah merek, sehingga dapat berkembang dan terjaga keberadaannya.

Hal ini menunjukkan jika kedekatan emosional antara pustakawan sebagai penyelenggara layanan storytelling dengan siswa dan guru sebagai pengguna layanan storytelling perlu dibentuk oleh pustakawan untuk menumbuhkan adanya intimacy, sehingga siswa dan pustakawan dapat merasa memiliki kedekatan dan komitmen untuk selalu mendukung layanan storytelling yang diselenggarakan oleh perpustakaan. 
Berdasarkan hasil penelitian ini, pelaksanaan layanan storytelling ini ternyata mampu memberikan dampak yang positif yaitu terjalinnya kedekatan emosional antara pustakawan dengan pemustaka, khususnya siswa SDN 035 Soka Bandung. Pada Perpustakaan SDN 035 Soka Bandung, kedekatan emotional melalui storytelling ini sudah terbentuk dengan adanya layanan di perpustakaan. Warga sekolah khususnya siswa sebagai pengguna layanan storytelling sudah merasa memiliki kedekatan dengan pustakawan dengan mendukung terselenggaranya layanan storytelling sebagai penyimak ataupun pencerita yang diadakan secara rutin. Hal ini sesuai dengan pernyataan informan berikut:

“...setelah diadakannya layanan storytelling di perpustakaan, siswa menjadi sering berkunjungdan pemanfaatan koleksi perpustakaan semakin meningkat. Efek ke anak juga terlihat dan antusias saat kegaitan berlansung... sangat produktif dalam meningkatkan minat anak" (I1/CC/KP/04-2017/4)

“...setelah anak lelah berfikir dan belajar di kelas anak pun memanfaatakan perpustakaan dengan mereka mendengarkan storytelling yang di sampaikan oleh pustakawan dan itu sangat membantu tugas guru dalam mendidik siswa" (I3/YM/GR/04-2017/1)

Dalam melihat bagaimana bentuk kedekatan emosional yang terjadi dapat melalui penerapan emotional branding di Perpustakaan 035 Soka Bandung. Dalam penerapan emotional branding ini didasarkan pada 4 pilar, yaitu hubungan, pengalaman panca indera, imajinasi, dan visi (Gobe, 2005). Adapun bentuk implementasi dan dampaknya adalah sebagai berikut:

\section{Hubungan}

Pilar hubungan merupakan pilar yang berkaitan dengan kemampuan organisasi dalam menumbuhkan hubungan mendalam, sehingga mampu mengetahui siapa konsumennya (Gobe, 2005). Implementasi pilar hubungan pada Perpustakaan SDN 035 Soka Bandung terwujud dalam kemampuan pustakawan dalam menumbuhkan hubungan yang mendalam dan mengenal siapa konsumen atau penggunanya dengan memenuhi kebutuhan siswa dan guru sebagai pengguna layanan storytelling di Perpustakaan SDN 035 Soka Bandung. Hal ini terlihat dari baiknya upaya yang dilakukan oleh perpustakaan melalui kepala perpustakaan dan staff pustakawan dalam mengembangkan program storytelling sebagai salah satu layanan di perpustakaan SDN 035 Soka Bandung.

Selain itu, pelaksanaan program storytelling yang dikembangkan perpustakaan juga bertujuan untuk menumbuhkan hubungan antara perpustakaan sebagai penyedia layanan dan sumber informasi dengan warga sekolah sebagai konsumen, khususnya adalah siswa. Perpustakaan dapat dinilai sebagai keseluruhan unsur yang ada didalamnya, baik pustakawan, koleksi, tempat, layanan dan hal lainnya yang diberikan kepada konsumen. Hal ini sesuai dengan kutipan wawancara pustakawan berikut: 
“...mengadakan program storytelling di perpustakaan bertujuan untuk meningkatkan minat kunjung siswa serta literasi siswa yang sekarang telah terlihat bahwa buku sudah hampir tergantikan oleh Smartphone melalui internet maka dengan pustakawan mengadakan storytelling siswa akan mengenal bentuk cetak sebuah informasi yang menyenangkan contohnya koleksi buku cerita, dan buku fabel anak tanpa terpaku hanya pada HP. Kegiatan Storytelling mampu mengarahkan siswa dalam pemanfaatan koleksi perpustakaan” (I2/SL/PS/04-2017/2)

Sedangkan bagi guru sekolah, program storytelling yang dilaksanakan di sekolah dapat membantu guru dalam proses pembelajaran untuk mengembangkan siswa dari berbagai aspek. Hasil interprestasi data dari wawancara singkat ke siswa, disimpulkan bahwa perpustakaan menjadi tempat yang menyenangkan, baik dari segi tempat, koleksi, tenaga pengelola atau pustakawan bahkan layanan yang diberikan.

Berdasarakan analisis tersebut dapat diketahui bahwa layanan storytelling mampu membangun hubungan positif antar warga sekolah dengan perpustakaan, terutama guru dan para siswa. Adapun bagi siswa, layanan storytelling dianggap sebagai layanan yang menarik karena mampu menciptakan hubungan yang baik dengan menjadikan pustakawan sebagai teman dalam bercerita. Tentunya hubungan positif ini tercipta dengan adanya upaya atau strategi pustakawan menciptakan citra atau image positif melalui kegiatan yang diselenggarakan. Hal ini sesuai dengan pendapat Komariah et al. (2016) yang menyebutkan peran pustakawan sebagai peran kunci atau tulang punggung layanan perpustakaan. Dengan peran tersebut, pustakawan haruslah dapat mengembangkan strategi dalam membina hubungan dengan pemustaka atau konsumen secara baik dan intim/mendalam. Jika kesan yang diciptakan terhadap pustakawan kepada pemustaka adalah kesan yang positif maka akan membuat kesan pemustaka menjadi nyaman di perpustakaan.

Hal tersebut juga didukung hasil penelitian Setiaji, Winoto, \& Khadijah (2012) dimana persepsi siswa terhadap pustakawan akan baik jika pustakawan dapat membantu siswa dalam memberikan pelayanan yang maksimal di perpustakaan. Ditambahkan siswa akan merespon positif jika pustakawan aktif mengajak anggota perpustakaan khususnya siswa dalam berdiskusi, membaca ataupun membantu penelusuran informasi. Dengan banyaknya tindakan positif yang diberikan pustakawan pada perpustakaan dalam melayani pemustaka akan menciptakan kedekatan emotional pemustaka terhadap perpustakaan, sehingga pemustaka nyaman, puas dan memberikan sikap positif terhadap perpustakaan.

\section{Pengalaman panca indera}

Pilar pengalaman panca indera merupakan sebuah prodak harus mampu memberikan pengalaman panca indera yang dapat menimbulkan kenangan dan loyalitas konsumennya (Gobe, 2005). Implementasi pilar pengalaman panca indera pada Perpustakaan SDN 035 Soka 
Bandung terwujud dalam kemampuan pustakawan dalam menyajikan layanan storytelling dengan teknik pemberian gambar, ekspresi wajah, intonasi suara dan literasi alam, sehingga memberikan pengalaman panca indera kepada siswanya. Hal ini sesuai dengan pernyataan informan berikut:

"Sejauh ini kita hanya menggunakan media buku fabel untuk kelas bahwa karena lewat gambar dan imajinasi anak akan lebih mudah terbentuk, dan untuk kelas atas kadang kita menggunakan ekspresi wajah dalam penyampaian cerita serta intonasi suara tokoh dalam buku kita bedakan agar pendengar mampu membedakannya dan menuntun kan alur cerita yang mudah di pahami oleh anak, kadang setelah kita bercerita kita memberikan kesempatan pada anak untuk menceritakan kembali dengan gaya mereka pada temannya." (I1/CC/KP/04-2017/2)

“Teknik yang lain kita menggunakan yang namanya literasi alam dimana anak kita bawa jalan-jalan contoh di sekeliling sekolah dan anak kita suruh menuliskan dengan apa yang mereka lihat suatu benda misalkan pohon beringin nah mereka kita suruh untuk menuliskan kedalam buku baik melalui cerita ataupun puisi yang nantinya akan di ceritakan atau di bacakan di depan teman temannya karena dengan begitu akan melatih fokus, dan daya imajinasi siswa yang kemudian akan melatih anak dapat berbicara di depan orang banyak" (I1/CC/KP/04-2017/2)

Berdasarkan hasil wawancara tersebut, pengalaman siswa dalam mengikuti program storytelling yang diselenggarakan perpustakaan akan menciptakan kenangan dan loyalitas pada perpustakaan.Hal ini akan terjadi jika penyampaian dalam proses storytelling dilakukan dengan baik sesuai dengan bagaimana mestinya. Terlihat dari keberlangsungan program yang diselenggarakan terus-menerus dengan respons siswa dan guru yang baik, pustakawan telah menciptakan hubungan emosional melalui proses pengalaman panca indera ini sendiri. Pada penelitian ini, hasil observasi menemukan bahwa pustakawan belum maksimal dalam menggunakan media pada strorytelling hanya menggunakan media buku atau koleksi yang digunakan oleh perpustakaan saja. Hal ini juga menjadi temuan berdasarkan hasil wawancara singkat kepada siswa yang mengharapkan pustakawan dapat menggunakan alat peraga yang beragam dalam penyampaian storytelling seperti boneka, boneka tangan, wayang dan lainnya. Menurut penelitian Maulani, Hadifah, \& Pudyaningtyas (2016), salah satu media yang dapat digunakan dalam storytelling adalah media boneka tangan. Hal ini dinilai dapat meningkatkan kemampuan anak dalam mengingat cerita karena akan menarik perhatian dan cerita yang disampaikan pada anak menjadi lebih berkesan.

Penggunaan media bukanlah satu-satunya unsur dalam storytelling berkaitan dengan optimalisasi pengalaman panca indera. Selain itu terdapat penggunaan emosi dalam bercerita juga menjadi bagian penting. Hal ini berkaitan dengan penggunaan suara dan intonasi, ekspresi 
wajah, gerak tubuh dan bahasa tubuh (Mokhtar et al., 2011) menjadi hal yang penting dalam storytelling untuk meningkatkan pengalaman panca indera siswa saat mengikuti program.

\section{Imajinasi}

Pilar imajinasi merupakan salah satu pada proses emotional branding berupa pendekatan imajinatif dalam design produk, kemasan, toko ritel, iklan, dan situs web yang melampaui harapan konsumen dan meraih hati konsumen (Gobe, 2005). Implementasi pilar imajinasi pada Perpustakaan SDN 035 Soka Bandung terwujud dalam kemampuan pustakawan dalam mengemas layanan storytelling menjadi suatu kegiatan yang menyenangkan, sehingga siswa antusias untuk mengikuti storytelling. Layanan storytelling dikemas dengan memadukan kegiatan literasi alam seperti berjalan-jalan berkeliling area sekolah. Adanya kegiatan literasi alam ini menjadikan siswa dapat belajar mengenal lingkungan sekitar mereka.

Pada penelitian ini, storytelling tentunya dapat mengembangkan imajinasi mereka dari cerita yang disampaikan oleh pustakawan. Berkaitan dengan emotional branding, imajinasi yang dibangun adalah pendekatan tentang produk yang diberikan pustakawan pada siswa, yakni kemampuan dasar literasi seperti membaca dan menulis. Kemasan program yang menyenangkan membuat siswa dan guru merespons positif dan secara tidak langsung juga mengembangkan beberapa kemampuan mereka dalam literasi seperti menulis dan membaca. Menurut Wardiah (2017), storytelling menjadikan anak-anak kreatif tidak hanya aspek intelektual namun juga aspek lainnya seperti daya imajinasi dan fantasi, seni, emosi yang menyeimbangkan antara kemampuan otak kiri dan otak kanan.

Selain itu, pendekatan yang diberikan juga membangun imajinasi siswa tentang pustakawan sekolah yang pandai dalam menyampaikan cerita. Hal ini tentunya menciptakan image atau citra tentang pustakawan yang tidak hanya bekerja menjaga perpustakaan, mengatur buku dan melayani peminjaman saja. Namun juga secara aktif mempromosikan koleksi dengan layanan storytelling sehingga perpustakaan juga menjadi tempat rekreatif siswa di sekolah.

\section{Visi}

Pilar visi dalam emotional branding berkaitan dengan bagaimana sebuah merek harus memiliki visi yang kuat, sehingga dapat berkembang dan terjaga keberadaannya (Gobe, 2005). Diteruskan, beberapa aspek dalam visi ini berkaitan dengan pemenuhan layanan, inovasi produk dan layanan. Impelementasi pada pilar ini melalui layanan storytelling adalah optimalisasi perpustakaan yang dilakukan oleh pustakawan bersama kepala perpustakaan. Secara bersamasama dengan dukungan kepala sekolah, guru dan orang tua serta stakeholder lainnya, perpustakaan mengembangkan layanan dasar dan layanan yang bersifat unggulan yang ada di perpustakaan. Berdasarkan hasil observasi, layanan pokok atau dasar yang tersedia pada 
perpustakaan SDN 035 Soka Bandung diantaranya layanan bimbingan membaca (pengenalan kegiatan membaca pada siswa kelas rendah), layanan sirkulasi (peminjaman, dan pengembalian), layanan referensi (rujukan), layanan ruang baca, serta layanan storytelling sebagai layanan unggulan dalam mendukung literasi siswa.

Berdasarkan hasil penelitian ini, perpustakaan dinilai sudah memaksimalkan layanan perpustakaan dengan melakukan pengembangan layanan perpustakaan yang berkelanjutan. Pengembangan layanan pun juga dilakukan berdasarkan kebutuhan emosional dengan publik pemakai yakni warga sekolah itu sendiri yang terdiri atas guru dan siswa. Selain mengembangkan layanan dari segi kualitas dan kuantitas, perpustakaan pada penelitian ini juga ditemukan mengembangkan aspek lain yakni koleksi dan kompetensi pustakawan, khususnya dalam penyampaian storytelling.

Pada penelitian ini, keempat pilar ini sudah dioptimalkan dan berjalan dengan baik yang digerakkan oleh komponen kunci yakni pustakawan dan target pasar adalah pemustaka potensial yakni siswa dan guru. Storytelling menjadi salah satu program unggulan yang dapat digunakan perpustakaan sebagai strategi dalam emotional branding untuk meningkatkan kedekatan emosional perpustakaan, termasuk pustakawan dengan pemustaka, meningkatkan citra atau image perpustakaan menjadi lebih positif yang tidak hanya sebagai tempat/sumber informasi namun juga sarana rekreatif siswa serta meningkatkan loyalitas pemustaka terhadap perpustakaan. Dengan adanya strategi ini, pemustaka diharapkan mendapatkan kepuasan tersendiri dalam memanfaatkan layanan perpustakaan sekolah yang diberikan serta memiliki nilai positif sebagai nilai tambah pada pemustaka.

\section{SIMPULAN}

Hasil penelitian ini menunjukkan layanan storytelling dapat diaplikasikan dan diimplementasikan bagi perpustakaan sekolah dalam mengembangkan layanan khususnya di perpustakaan sekolah dasar. Pada penelitian yang dilakukan di Perpustakaan SDN 035 Soka Bandung, program storytelling juga berkorelasi dalam pengembangan dan peningkatan literasi siswa sesuai sebagai langkah dalam mendukung Gerakan Literasi Sekolah (GLS) yang dikenalkan oleh Kementerian Pendidikan dan Kebudayaan (Kemdikbud). Impelementasi program storytelling yang dilakukan di SDN 035 Soka Bandung dikategorikan pada tahap pembiasaan program Gerakan Literasi Sekolah, dimana tahap ini merupakan tahap awal penyelenggaraan gerakan literasi sekolah di lingkungan sekolah dasar.

Penyelenggaraan program storytelling oleh perpustakaan memberikan banyak dampak positif bagi siswa menurut guru dan pustakawan yakni menumbuhkan daya ingat dan daya berpikir siswa, meningkatkan siswa dalam berpikir kreatif dan melatih siswa dalam mendengarkan dan berkomunikasi.Sedangkan beberapa dampak positif dari siswa adalah 
meningkatkan minat kunjung ke perpustakaan, meningkatkan minat baca dan menulis serta meningkatkan kemampuan komunikasi siswa.

Hasil analisis program storytelling melalui konsep pilar emotional branding yang terdiri atas pilar hubungan, pengalaman panca indera, imajinasi dan visi menunjukkan bahwa program storytelling dapat menjadi strategi perpustakaan dalam meningkatkan emotional branding kepada konsumen atau siswa di perpustakaan sekolah. Strategi ini dapat meningkatkan kedekatan emosional perpustakaan dengan penggunanya sehingga menjadi lebih loyal menggunakan layanan perpustakaan. Pada strategi ini, pustakawan menjadi aKtor kunci dalam menjalankan emotional branding dengan menciptakan citra positif tentang perpustakaan dan pustakawan kepada masyarakat pengguna. Hal yang dilakukan perpustakaan adalah mengembangkan kompetensi diri dalam pelayanan storytelling, mengembangkan koleksi perpustakaan dan meningkatkan kualitas dan kuantitas layanan perpustakaan sehingga tercipta kepuasan tersendiri bagi pemustaka terhadap layanan yang diberikan dan membuat pemustaka menjadi loyal menggunakan perpustakaan.

\section{DAFTAR PUSTAKA}

Agosto, D. E. (2016). Why Storytelling Matters: Unveiling the Literacy Benefits of Storytelling. Children and Libraries, 14(2), 21-26.

Akgün, A. E., Koçoğlu, İ., \& İmamoğlu, S. Z. (2013). An Emerging Consumer Experience :

Emotional Branding. Procedia - Social and Behavioral Sciences, 99, 503-508. https://doi.org/10.1016/j.sbspro.2013.10.519

Antasari, I. W. (2017). Implementasi Gerakan Literasi Sekolah Tahap Pembiasaan di MI Muhammadiyah Gandatapa Sumbang Banyumas. LIBRIA, 9(1), 13-26.

Asri, T. M., Wulandari, E. R. N., \& Jariyah, U. (2019). Penerapan Storytelling dan Instagram: Optimalisasi Layanan Perpustakaan Keliling di Dinas Kearsipan dan Perpustakaan Kabupaten Kediri. Jurnal Baca, 40(2), 237-250. https://doi.org/10.14203/j.baca.v40i2.478

Bafadal, I. (2011). Pengelolaan Perpustakaan Sekolah. Jakarta: Bumi Aksara.

Devi, S., \& Sharma, R. (2015). Emotional Branding: Connecting Customer Via Heart. https://doi.org/http://dx.doi.org/10.2139/ssrn.2698553

Gobe, M. (2005). Emotional Branding: Paradigma baru untuk menghubungkan merek dengan pelanggan. Jakarta: Erlangga.

Indriani, W., Johan, R. C., \& Agustina, S. (2017). Konstruksi Program Storytelling (Studi Kasus pada Komunitas Dongeng Bengkimut di Pustakalana Children’s Library). Edulibinfo, 4(2).

Kementerian Pendidikan dan Kebudayaan RI. (2016). Panduan Gerakan Literasi Sekolah di 
Sekolah Dasar. (P. Wiedarti \& Kisyani-Laksono, Eds.). Jakarta: Direktorat Pembinaan Sekolah Dasar Kemendikbud.

Komariah, N., Rodiah, S., \& Saepudin, E. (2016). Emotional Branding sebagai Upaya

Pengembangan Kualitas Layanan Perpustakaan untuk Meningkatkan Penggunaan Perpustakaan. Record and Library Journal, 2(2), 188-197.

Lasa, H. (2013). Manajemen Perpustakaan Sekolab/Madrasah. Yogyakarta: Ombak.

Maulani, W., Hadifah, R., \& Pudyaningtyas, A. R. (2016). Peningkatan kemampuan mengingat cerita melalui metode bercerita dengan media boneka tangan pada anak kelompok B TK Masyitoh IV Surakarta tahun ajaran 2015/2016. Kumara Cendekia: Jurnal Pendidikan GuruPendidikan Anak Usia Dini, 4(2), 1-6.

Merga, M. K. (2019). How do librarians in schools support struggling readers ? English in Education, 53(2), 145-160. https://doi.org/10.1080/04250494.2018.1558030

Miles, M. ., Huberman, A. ., \& Saldana, J. (2014). Qualitative Data Analysis: A Methods Sourcebook. New York: Sage Publication.

Mokhtar, N. H., Halim, M. F. A., \& Kamarulzaman, S. Z. S. (2011). The Effectiveness of Storytelling in Enhancing Communicative Skills. Procedia - Social and Behavioral Sciences, 18, 163-169. https://doi.org/10.1016/j.sbspro.2011.05.024

Oriogu, C. D. (2015). Catch Them Young: Developing and Improving of School Libraries and Reading Habit of Secondary School Students in Nigeria. Journal of Education and ELearning Research, 2(4), 60-63.

Pratiwi, R. R. (2016). Penerapan Metode Storytelling untuk Meningkatkan Keterampilan Berbicara Siswa Kelas II SDN S4 Bandung. Jurnal Pendidikan Guru Sekolah Dasar, 1(1), 199-207.

Reitz, J. M. (2004). Online Dictionary for Library and Information Science. ABC-CLIO. Westport: Libraries Unlimited.

Rosidatun, R. (2018). Model Implementasi Pendidikan Karakter. Gresik: Caramedia Communication.

Setiaji, W., Winoto, Y., \& Khadijah, U. L. (2012). Persepsi Siswa Tentang Pustakawan di Perpustakaan Sekolah. EJurnal Mahasiswa Universitas Padjadjaran, 1(1), 1-12.

Sophiani, P. (2008). Peran Storytelling Sebagai Sarana Promosi Perpustakaan TK/SD Al-Izhar Pondok Labu. Universitas Islam Negeri Syarif Hidayatullah.

Sturm, B. W., Riddle, M., \& Fox, L. (2017). Storytelling's Impact on School Library Circulation. School Libraries Worldwide, 23(1), 14265.

Sumiati, O. (2018). Pengelolaan Perpustakaan Sekolah. Tangerang Selatan: Universitas Terbuka. Sutarno, N. . (2006). Perpustakaan dan Masyarakat. Jakarta: Sagung Seto. 
Turri, A. M., Smith, K. H., \& Kemp, E. (2013). Developing affective brand commitment through social media. Journal of Electronic Commerce Research, 14(3), 201-214.

Wardiah, D. (2017). Peran Storytelling dalam Meningkatkan Kemampuan Menulis, Minat Membaca dan Kecerdasan Emosional Siswa. Wahana Didaktika, 15(2), 42-56.

Yolanda, C., \& Hermintoyo, H. (2014). Pengaruh Pemberian Kegiatan Storytelling terhadap Minat Kunjung Anak ke Perpustakaan: Studi Kasus pada Perpustakaan Komunitas Jendela Semarang. Jurnal Ilmu Perpustakaan, 3(1), 22-34.

Yulfiandri, Y., \& Nelisa, M. (2015). Efektivitas kegiatan storytelling bahan pustaka untuk meningkatkan pengunjung anak usia dini di perpustakaan Proklamator Bung Hatta Bukittinggi. Jurnal Ilmu Informasi Perpustakaan Dan Kearsipan, 4(1), 263-270.

Yuliawati, L. (2008). Karakteristik kedekatan emosional orangtua sebagai model dan mentor kecerdasan emosional remaja. Sosiohumaniora, 10(2), 48-57. 